\title{
Corporate Social Responsibility, Good Corporate Governance, and Management Compensation against Tax Avoidance
}

\author{
Yeyet Rohyati' ${ }^{1}$, Suripto ${ }^{2}$ \\ 1,2 Pamulang University, Indonesia \\ yeyetrohyati8@gmail.com,dosen00756@unpam.ac.id
}

\begin{abstract}
This study aims to obtain empirical evidence regarding the influence of Corporate Social Responsibility, Good Corporate Governance, and Management Compensation on Tax Avoidance. The population in this study are mining companies listed on the Indonesia Stock Exchange in 2016-2018. Determination of the sample using purposive sampling technique, obtained a sample of 8 companies with 40 observational data. The analysis technique and hypothesis testing are carried out by using panel data regression analysis through Eviews-9. The results show that Corporate Social Responsibility has a positive effect on Tax Avoidance, Good Corporate Governance has no effect on Tax Avoidance, and Management Compensation has a negative effect on Tax Avoidance.
\end{abstract}

\section{Keywords}

corporate social

responsibility; good

corporate governance;

management

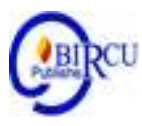

\section{Introduction}

One of the biggest sources of state revenue is tax revenue. The amount of state revenue from taxes is influenced by the level of taxpayer compliance. For the company, tax is a burden so it becomes a significant concern, because for the company tax can reduce the amount of net profit that the company will receive, so that the company reduces tax payments as low as possible. Various efforts can be made by companies in reducing the amount of tax burden that must be paid (Cita \& Supadmi, 2019). In Indonesia, there are still tax avoidance practices, this is due to the lack of awareness of taxpayers which has an impact on the tax ratio in Indonesia which is still below 15\%. During the last 5 years the tax ratio has only reached $10 \%$ to $12 \%$, so there is still potential to increase taxpayer compliance (Rosadi, 2019)

The Directorate General of Taxes (DGT) investigates allegations of tax avoidance committed by the coal company PT. Adaro Energy Tbk, with a scheme transfer pricingthrough a subsidiary located in Singapore. The tax evasion report was reported by the international NGO Global Witness which is engaged in environmental issues by publishing an investigative report on the alleged tax evasion of Adaro Energy companies. In this report, it is indicated that Adaro is driving its revenue and profits abroad so that it can reduce the taxes paid to the Government of Indonesia. Global Witness said this was done by selling coal at low prices to a subsidiary of Adaro in Singapore, under the company name Coaltrade Services International for resale at a high price. Through this company, Global Witness discovered the potential for paying a lower than expected tax value of US \$ 125 million to the Indonesian government (Friana, 2019).

Tax Avoidance is carried out by a company because the rates imposed by the government are too high on the company. Taxes collected by the State function as a tool to regulate and implement policies in the social and economic fields and are used for the 
welfare of the people (Damayanti \& Susanto, 2016). Corporate and individual taxpayers are expected to comply with their tax obligations voluntarily and comply with tax regulations (Sidiq \& Jalil, 2021; Dharma \& Ardiana, 2016)

Tax avoidance behavior aims to reduce the tax burden on the company while still complying with the provisions of tax regulations, such as taking advantage of allowable exemptions and deductions or postponing taxes that have not been regulated in the applicable tax regulations and usually through policies taken by the leadership of the company (Dewinta \& Setiawan, 2016).

Even though tax avoidance is legal, the government still doesn't want it. Approximately $25 \%$ of company profits are paid for taxes thus providing incentives for companies to invest in tax planning activities thereby increasing the probability of the company being identified by tax authorities involved in tax evasion.(Chaudhary, 2016). Fenomena differences in interests between taxpayers and the government and the average tax ratio that has not reached the target can indicate a large enough tax avoidance activity, so that Indonesia's state tax revenue is still not optimal.

Corporate Social Responsibility regulated in Law of the Republic of Indonesia Number 40 of 2007 concerning Limited Liability Companies Article 74 Social and Environmental Responsibility. So that it requires companies to carry out social responsibility activities. Since the enactment of laws governing Corporate Social Responsibility, more and more companies have implemented Corporate Social Responsibility programs to maintain their reputation and business continuity.(Gantino, 2016); (Sri Ardani \& Mahyuni, 2020).

(Hidayat et al., 2016)examined the Effect of Corporate Social Responsibility on Tax Avoidance. The results showed that the independent variable Corporate Social Responsibility had a positive effect on Tax Avoidance. In managing company activities, companies need to improve good corporate governance in order to ensure that company management runs well. It is hoped that implementation can balance the many interests and maximize profits for the company (Indonesia PUGCG, 2006)

To increase market confidence so as to encourage investment flows and sustainable national economic growth, companies are required to improve and enhance the competitiveness of companies both nationally and internationally, in connection with this the Indonesian government and the International Monetary Fund (IMF) introduced the concept of Good Corporate Governance in 1999 with the formation of National Committee for Corporate Governance Policy (KNKCG).

Based on the Decree of the Coordinating Minister for Economy Number: KEP / 31 / M.EKUIN / 08/1999. Companies that have a Good Corporate Governance mechanism will comply with their tax obligations(Winata, 2014). Several studies on Good Corporate Governance against Tax Avoidance have been conducted. The research has been carried out by, among others.(Oliviana \& Muid, 2019), (Chasbiandani et al., 2020)

Management has the authority to use its power in the company to make strategic policies with the aim of increasing efficiency when using the resources owned by the company. Tax avoidance is an example of a strategy that can be used by company management to make savings on company expenses which in turn can increase the company's net income. Mayangsari, et al (2015) and (Budiadnyani, 2020) prove that there is a negative effect between management compensation and tax avoidance. (Dewi \& Sari, 2015) which states that management compensation has no effect on tax avoidance.

Tax avoidance cases that are detrimental to the state and proven by the Directorate General of Taxes (DGT), one of which is PT. Bumi Resources Tbk. Tax evasion of PT Bumi Resources and its subsidiaries, namely PT Kaltim Prima Coal (KPC) and PT 
Arutmin Indonesia, reached 2.1 trillion, for which the DGT has named the finance director of PT Bumi Resources and the director of PT Kaltim Prima Coal as criminal suspects of tax evasion (Budiadnyani, 2020). Based on the phenomenon of tax avoidance and research gap as revealed in the background of this study, research on Corporate Social Responsibility, Good Corporate Governance, Management Compensation, and Tax Avoidance is important to do.

\section{Review of Literature}

\subsection{Agency Theory}

Agency theory is a theory that explains the relationship between the principal and the manager (agent) in managing the company to achieve Good Corporate Governance. Principle is a group of people who have an interest in the company and delegate the authority they have to the agent, namely management (Company et al., 1976). In agency theory, agency relations arise when one or more people (principal) employ another person (agent) to provide services and then delegate decision-making authority to that agent. The relationship between the principal and the agent can lead to an imbalance of information between the principal and the agent (asymmetrical information) because the agent is in a position to have more information about the company than the principal.

\subsection{Stakeholder Theory}

Stakeholdersthere isis any group or individual that can influence or be influenced by the achievement of organizational goals. Stakeholders can be divided into two based on their characteristics, namely primary stakeholders and secondary stakeholders. Primary stakeholder is a person or group without which the company cannot survive a going concern, including: shareholders and investors, employees, consumers and suppliers, together with those defined as public stakeholder groups, namely: government and

communities. Secondary stakeholder groups are defined as those who influence, or are influenced by the company, but they are not related to transactions with the company and are not essential to its survival.

This theory states that organizations will choose to voluntarily disclose information about their environmental, social and intellectual performance, over and above its mandatory demands, in order to meet actual or recognized expectations of stakeholders. Stakeholder theory assumes that the company's existence requires stakeholder support, so that the company's activities also consider stakeholder approval(Rokhlinasari, 2016). This theory is in accordance with previous research because one of the variables is Good Corporate Governance which has an audit committee proxy so that it has a significant positive effect on tax avoidance.

\subsection{Legitimacy Theory}

Legitimacy theory focuses on the interaction between companies and society. This can be used as a vehicle for constructing company strategy, especially in relation to efforts to position oneself in the midst of society. Legitimacy Theory states that organizations must continuously ensure whether they have operated within norms that are upheld by society and ensure that company activities can be accepted by parties outside the company.

This research requires social values, in which there is a Corporate Social Responsibility variable. Research on the relationship between Corporate Social Responsibility and tax avoidance has been researched first by several researchers, including (N. Dharma, 2017) (in the Journal of the Influence of Corporate Social 
Responsibility and Capital Intensity on Tax Avoidance 2017), which found that the higher the level of corporate social responsibility, the lower the level of tax avoidance.

\subsection{Tax Evasion}

Tax avoidance can be contained in the provisions of laws and regulations and is in the soul of the regulation. Or contained in statutory regulations but not in the spirit of the regulation (Setyaningsih, 2018). According toAnwar (2016: 23) Tax avoidance is: "Tax avoidance efforts that are carried out legally and safely for taxpayers because they do not conflict with taxation provisions, where the methods and techniques used tend to take advantage of the weaknesses contained in tax laws and regulations themselves, to minimize taxation the amount of tax due". From the explanation regarding tax avoidance above, it can be concluded that tax avoidance is a tax avoidance effort that has an effect on tax obligations that is carried out by still being within the scope of taxation provisions.

\subsection{Corporate Social Responsibility}

Corporate Social Responsibility present as the company's response to society and the environment as a form of responsibility (Suripto, 2019). Corporate social responsibility (Corporate Social Responsibility) is the company's voluntary commitment to participate in improving the welfare of the community and is not a business activity that is required by law and legislation such as the obligation to pay taxes or company training in labor laws.(Solihin, 2018).

Corporate Social Responsibilityis a necessity for corporations to be able to interact and communicate locally with the community as a whole. Corporate Social Responsibility is of course closely related to corporate culture and business ethics that must be owned by corporate culture, because to carry out Corporate Social Responsibility a culture based on adaptive ethics is needed.(Rudito et al, 2013: 1). From the definition of the experts above, Corporate Social Responsibility is a company activity as a responsibility towards the environment in order to gain the trust of the community (Kunyanti, 2021).

\subsection{Good Corporate Governance}

Good Corporate Governance is a system (input, process, output) and a set of regulations governing the relationship between various interested parties (stakeholders), especially in the narrow sense of the relationship between shareholders, the board of commissioners and the board of directors for the achievement of objectives. company. Good Corporate Governance is included to regulate these relationships and prevent significant mistakes in the company's strategy and to ensure that mistakes that occur can be corrected immediately(Zarkasyi, 2019: 96). From the definitions of the experts above, it can be concluded that Good Corporate Governance is a system used as corporate governance in order to create prosperity for all parties.

\subsection{Management Compensation}

According toSikula (1981: 55) Compensation is a very broad concept of employee remuneration which includes administration, salaries and wages and benefits, and services for employees. Compensation for a company can be in the form of salary, bonus, allowance, or other additional income. Salary is a company fixed payment to employees, while bonuses are based on individual key performance achievements for a period(Suripto, 2020) 


\section{Research Methods}

\subsection{The Influence of Corporate Social Responsibility on Tax Avoidance}

Corporate Social Responsibility is a business commitment to act ethically, contribute to economic development, improve the quality of life of workers, local communities and the wider community. The results of research conducted byHidayati \& Fidiana (2017) also shows that Corporate Social Responsibility has a positive effect on tax avoidance. Taxes and corporate social responsibility are both aimed at the general welfare. This explains that the number of Corporate Social Responsibility activities will encourage companies to be more open in disclosing Corporate Social Responsibility activities

\section{H1: It is suspected that Corporate Social Responsibility (CSR) has an effect on Tax} Avoidance

\subsection{The Influence Good Corporate Governance against Tax Avoidance}

According to the Forum for Corporate Governance on Indonesian (FCGI) in Effendi (2016) Corporate governance is a set of regulations that govern the relationship between shareholders, company managers, creditors, government, employees, and other internal and external stakeholders relating to their rights and obligations or a system that controls the company. Good corporate governanceprevious research has been carried out by several researchers. The results of the research conducted(Mahulae et al., 2016)concluded that good corporate governance has a significant effect on tax avoidance. Therefore, based on previous research, the second hypothesis can be formulated, namely:

\section{H2: It is suspected that Good Corporate Governance has an effect on Tax Avoidance}

\subsection{The Influence Management Compensation against Tax Avoidance}

Management compensation planning is the policies and procedures for providing compensation to managers and compensation can also be interpreted as all forms of financial returns, tangible services, and benefits obtained by employees as part of an employment relationship. Compensation can be in the form of salary, bonus, allowance, or additional income. Management compensation has been carried out in previous studies by several researchers. The results of the research conductedAmri (2017)shows that management compensation has an effect on tax avoidance. Therefore, based on previous research, the third hypothesis can be formulated, namely:

\section{H3: It is suspected that management compensation has an effect on Tax Avoidance}

This research is classified into quantitative research using secondary data as a source of research data. The population selection for this study were 45 mining companies listed on the IDX in 2016-2019. Determination of the sample using purposive sampling technique, obtained a sample of 8 companies with 40 observational data for 5 years.

Table 1. Sample Criteria

\begin{tabular}{|c|l|c|}
\hline No. & \multicolumn{1}{|c|}{ Information } & \multicolumn{1}{|c|}{ Amount } \\
\hline 1 & $\begin{array}{l}\text { Mining sector companies listed on the Indonesia Stock Exchange } \\
\text { (IDX) for the period 2015 - 2019 }\end{array}$ & 45 \\
\hline 2 & $\begin{array}{l}\text { Mining sector companies publish financial reports for the period } \\
2015-2019\end{array}$ & 88 \\
\hline 3 & $\begin{array}{l}\text { Mining sector companies that publish sustainability reports or } \\
\text { sustainability reports with core options during the research period }\end{array}$ & \multicolumn{2}{|c|}{} \\
\hline
\end{tabular}

Source: Processed data 
Data collection techniques used in this study are documentation techniques on secondary data. The data used is in the form of annual reports of mining companies listed on the IDX during 2016-2019. The data analysis technique used consists of descriptive statistics, panel data regression model selection, classical assumption testing (normality, multicollinearity, heteroskesdasticity, autocorrelation), panel data regression analysis, and hypothesis testing. This study uses four research variables consisting of one dependent variable and 3 independent variables.

\subsection{Measurement of Variables}

a. Tax Evasion

Tax avoidance in this study is measured using the ratio of effective tax rates (ETR). Effective Tax Rates (ETR) in this study only use the main model used(Lanis \& Richardson, 2013) that is, income tax expense divided by the company's income before tax. The Effective Tax Rates (ETR) ratio is measured as follows:

$$
\text { ETR }=\frac{\text { Payment of Taxes or Tax Expenses }}{\text { Profit before tax }}
$$

\section{b. Corporate Social Responsibility}

One indicator of CSR disclosure is the Global Reporting Initiative (GRI) Index. The content of the GRI Global Reporting Initiative used in this thesis is part of the GStandard.

Table 2. Global Reporting Initiative (GRI) Standard

\begin{tabular}{|c|l|}
\hline $\begin{array}{c}\text { Suspension } \\
\text { Index }\end{array}$ & \multicolumn{1}{c|}{ Information } \\
\hline 0 & No information was disclosed in accordance with the indicators \\
\hline 1 & Sentence \\
\hline 2 & Paragraph \\
\hline 3 & 2-3 Paragraphs \\
\hline 4 & 4-5 Paragraph \\
\hline 5 & > Paragraph \\
\hline
\end{tabular}

Source: (Gunawan and Abadi, 2017)

The final result of the content of this analysis will produce a score for the level of CSR disclosure in non-financial companies in Indonesia. The following is an explanation of the suspension index table 2

1) A score of 0 (zero) is given, if the information in the report is not disclosed in accordance with the indicator measurement, in this case it is a CSR measurement item

2) A score of 1 is given, if the diagram (picture, table or graph) expresses one word, or is considered a sentence. So a score of 1 will be given, if the disclosure contains at least one word or as much as 1 sentence

3) A score of 2 (two) is given, if the disclosure contains at least 2 sentences, it is considered as 1 paragraph

4) A score of 3 is given, if the disclosure contains 2 to 3 paragraphs

5) A score of 4 is given, if the disclosure contains 4 to 5 paragraphs

6) A score of 5 is given if the disclosure contains more than 5 paragraphs 


\section{c. Good Corporate Governance}

In this study, independent commissioners were measured according to research conducted by(Rahmawati et al., 2015). The number of members of the board of commissioners and independent commissioners can be seen in the audited Financial Statements in the General Information section of the Company or in the company's Annual Report in the Corporate Governance section of the board of commissioners structure section.

\section{$\sum$ Dewan Komisaris KOMIND $=\sum$ Komisaris Independen}

The audit committee was formed to assist the board of commissioners in improving the quality of financial reports and increasing the effectiveness of internal and external audits. The audit committee is in charge of monitoring to improve effectiveness in creating transparency and quality financial reporting, compliance with applicable laws and regulations, and adequate internal supervision.(Wulandari, 2018). The audit committee calculation is measured using the number of the company's audit committee(Wijayanti et al., 2016)

Audit Committee $=$ The total number of company audit committees

\section{d. Management Compensation}

The purpose of compensation is to align the interests of shareholders with the interests of company managers. Compensation can have long-term effects by using incentives in the form of shares or providing short-term incentives in the form of cash. Management compensation in this study uses an approach(Christopher et al, 2012)This approach uses the total compensation value received during the year by company executives and a compensation mix in the form of the ratio of each component of the compensation to the total compensation value received. The level of compensation given to the board of directors.

\section{Discussion}

\subsection{Descriptive Statistical Analysis}

Descriptive statistical analysis is explained by means of the mean, maximum, and minimum values. The results of descriptive statistical analysis in this study indicate that the averagecompanies do tax avoidance of $-109.6 \%$. The highest Tax Avoidance of $257.2 \%$ was obtained by the company PT. Timah (Persero) tbk. in 2018, while the lowest tax avoidance of $-342.7 \%$ was obtained by PT. Petrosea tbk. in 2015.

Table 3. Descriptive statistics

\begin{tabular}{|l|c|c|c|c|}
\hline & TA & CSR & GCG & KM \\
\hline Mean & -1.096482 & 5.668369 & 1.403215 & 26,96424 \\
\hline Median & -1.207919 & 5.678136 & 1.466337 & 27.22553 \\
\hline Maximum & 2.572235 & 6.368187 & 1,871802 & 28.95285 \\
\hline Minimum & -3.427744 & 4.828314 & 1.163151 & 22,71449 \\
\hline Std. Dev. & 0.988562 & 0.428754 & 0.173439 & 1.272086 \\
\hline Skewness & 1.187367 & -0.082944 & 0.447694 & -0.916636 \\
\hline Kurtosis & 7.089363 & 2.188006 & 2.657969 & 4.675443 \\
\hline & & & & \\
\hline Jarque-Bera & 37,27042 & 1.144754 & 1.531172 & 10.27999 \\
\hline Probability & 0.000000 & 0.564183 & 0.465061 & 0.005858 \\
\hline
\end{tabular}




\begin{tabular}{|l|c|c|c|c|}
\hline & & & & \\
\hline Sum & -43.85928 & 226.7348 & 56.12858 & 1078,570 \\
\hline Sum Sq. Dev. & 38.11295 & 7.169376 & 1.173161 & 63.10995 \\
\hline Observations & 40 & 40 & 40 & 40 \\
\hline
\end{tabular}

Source: Data processed with Eviews9

\subsection{Panel Data Regression Model Selection}

There are three panel data regression models that can be used to perform panel data regression analysis, namely the common effect model (CEM), the fixed effect model (FEM), and the random effect model (REM). The best model selection method that can be used in panel data regression analysis is obtained by performing three tests, namely the Chow test, the Hausman test, and the Lagrange multiplier test. The result of selecting the panel data regression model in this study, namely the chow test, shows the probability value of cross section $F$ of $0.0000<0.19$. The LM test shows a $p$ value of $0.5658>0.05$. So it can be concluded that the common effect model (CEM) is the right model to be used as a panel data regression model.

Table 4. Conclusion Panel Data Regression Model Testing

\begin{tabular}{|c|l|l|l|}
\hline No. & \multicolumn{1}{|c|}{ Method } & \multicolumn{1}{c|}{ Testing } & Result \\
\hline 1. & Chow-Test Test & Common effect $v$ s fixed effect & Common effect \\
\hline 2. & Lagrange Multiplier-Test & Common effect vs random effect & Common effect \\
\hline
\end{tabular}

Source: Data processed with Eviews 9

\subsection{Classic Assumption Test}

a. Multicolinearity

Multicolineartias occurs if the correlation of each independent variable is $>0.90$, while if the correlation value of each independent variable is $<0.90$, the regression model does not have a multicollinearity problem.(Ghozali, 2017). Based on multicollinearity testing with the help of Eviews 9, it shows the value for each independent variable of Corporate Social Responsibility (X1) with Good Corporate Governance (X2) and vice versa of 0.693100, Corporate Social Responsibility (X1) with Management Compensation (X3) and vice versa of 0,083150 . Meanwhile, the value of Good Corporate Governance (X2) with Management Compensation (X3) and vice versa is 0.394871 . These results indicate that each independent variable does not have a correlation value greater than 0.90 , so it can be said that there is no multicollinearity between the independent variables. Based on the multicollinearity test results of each variable, this regression model is free from multicollinearity because the tolerance value for each variable is $<0.90$. Then it can be concluded that the regression model is free from multicollinearity.

\section{b. Heteroscedasticity}

A good regression model is the variance of the same disturbance variable (homoscedasticity) or there is no heteroscedasticity (Ghozali, 2018). In this study, the heteroscedasticity test used the Glejser method. The basis for decision making if the significant value is $>0.05$, then heteroscedasticity does not occur. Based on the autocorrelation test with the help of Eviews 9, the prob value is obtained. Chi-square (3) is $0.1495>0.05$. Heteroscedasticity test results using the Glejser method, heteroscedasticity does not occur because the significant value is more than 0.05 . This means that the regression model is assumed not to be constrained by heteroscedasticity. 


\section{c. Panel Data Regression Analysis}

Based on the previous selection of regression models, the common effect model is the most appropriate regression model to be used in this study.

Table 5. Panel Data Regression Analysis Common Effect Model

Dependent Variable: TA

Method: Least Squares Panel

Date: 02/02/21 Time: 22:02

Sample: 20152019

Periods included: 5

Cross-sections included: 8

Total panel (balanced) observations: 40

\begin{tabular}{lrrrr}
\hline \hline \multicolumn{1}{c}{ Variable } & Coefficient & Std. Error & t-Statistic & Prob. \\
\hline \hline C & 0.313324 & 3.569898 & 0.087768 & 0.9305 \\
CSR & 0.979343 & 0.444424 & 2.203623 & 0.0340 \\
GCG & 0.806893 & 1.191686 & 0.677102 & 0.5027 \\
KM & -0.300150 & 0.117527 & -2.553882 & 0.0150 \\
\hline \hline R-squared & 0.362525 Mean dependent var & -1.096482 \\
Adjusted R-squared & 0.309402 SD dependent var & 0.988562 \\
SE of regression & 0.821517 Akaike info criterion & 2,539311 \\
Sum squared resid & 24.29604Schwarz criterion & 2.708199 \\
Log likelihood & -46.78622 Hannan-Quinn criter. & 2.600375 \\
F-statistic & 6.824278Durbin-Watson stat & 1.219615 \\
Prob (F-statistic) & 0.000929 & & \\
\hline \hline
\end{tabular}

Source: Data processed with Eviews 9

The regression equation from table 4 with the dependent variable enterprise risk management disclosure is as follows:

$$
\mathrm{Y}=0.313324+0.979343(\mathrm{CSR})+0.806893(\mathrm{GCG})-0.300150(\mathrm{KM})
$$

\section{d. Hypothesis Testing}

\section{F test}

Based on the panel data regression analysis test in table 5, it was found that $\mathrm{df} 1=\mathrm{k}$ (number of independent variables plus dependent variables) - 1, namely $4-1=3$. While df $2=\mathrm{n}$ (amount of data) $-\mathrm{k}$ (number of independent variables plus dependent variables), namely $40-3=37$, with alpha $(\alpha)=0.05$ so that it is known that the F-table value is 2.86 .

It is known that the results of the F-count of the variable corporate social responsibility, good corporate governance, and management compensation simultaneously are 6.824278 so that the F-count is greater than the F-table $(6.824278>2.86)$ or rejects $\mathrm{H} 0$ and accepts Ha1. Meanwhile, the probability value is smaller than the significance level of $0.05(0.0000<0.05)$ or rejecting $\mathrm{H} 0$ and accepting Ha1. So it can be concluded that the variables of corporate social responsibility, good corporate governance, and management compensation simultaneously have a positive and significant effect on tax avoidance

\section{Determination Coefficient Test (adjust r2)}

In table 5 it can be seen that the adjusted R2 value is 0.309 . This means that the variation of the independent variables (Corporate Social Responsibility, Good Corporate Governance, and Management Compensation) is able to explain the variation of the 
dependent variable (Tax Avoidance) by $30.9 \%$ while the remaining $60.1 \%$ is a variation of other independent variables that affect tax avoidance but not included in the model.

\section{3. $T$ test}

The $t$ test in this study was carried out with assistanceEviews 9to analyze panel data regression using a common effect model. The t-test decision making is done by looking at the t-table value, to obtain the t-table value it is necessary to find df (degree of freedom) with the formula $\mathrm{df}=\mathrm{n}$ (amount of observation data) - $\mathrm{k}$ (number of independent variables plus dependent variables). So in this study obtained $\mathrm{df}=40-4=36$ and a significance level of $0.05 / 2$, in order to obtain a t-table of 2.02809 (two-way test).

\section{The Influence of Corporate Social Responsibility on Tax Avoidance}

Table 6. The Influence of Corporate Social Responsibility on Tax Avoidance

Dependent Variable: TA

Method: Least Squares Panel

Date: 02/02/21 Time: 22:02

Sample: 20152019

Periods included: 5

Cross-sections included: 8

Total panel (balanced) observations: 40

\begin{tabular}{|c|c|c|c|c|}
\hline Variable & Coefficient & Std. Error & t-Statistic & Prob. \\
\hline C & 0.313324 & 3.569898 & 0.087768 & 0.9305 \\
\hline CSR & 0.979343 & 0.444424 & 2.203623 & 0.0340 \\
\hline
\end{tabular}

Source: Data processed with Eviews 9

Table 6 shows that the p-value is smaller than 0.05 . When compared with the alpha value of $5 \%$, this significance value is smaller $(0.0340<0.05)$ and the t value is 2.2036 . From these results, it can be concluded that Corporate Social Responsibility has a positive effect on Tax Avoidance because the greater the Corporate Social Responsibility activities carried out by the company, it will increase tax avoidance actions by companies. Besides, some pa company that carries out social responsibility solely uses social responsible actions to get a positive image so that the company can cover up their socially irresponsible actions such as tax avoidance.

\section{The Effect of Good Corporate Governance on Tax Avoidance}

Table 7. The Effect of Good Corporate Governance on Tax Avoidance

Dependent Variable: TA

Method: Least Squares Panel

Date: 02/02/21 Time: 22:02

Sample: 20152019

Periods included: 5

Cross-sections included: 8

Total panel (balanced) observations: 40

\begin{tabular}{|c|c|c|c|c|}
\hline Variable & Coefficient & Std. Error & t-Statistic & Prob. \\
\hline C & 0.313324 & 3.569898 & 0.087768 & 0.9305 \\
\hline GCG & 0.806893 & 1.191686 & 0.677102 & 0.5027 \\
\hline
\end{tabular}

Source: Data processed with Eviews 9 
Table 7 shows that the p-value is greater than 0.05 . When compared with an alpha value of $5 \%$, this significance value is greater $(0.5027>0.05)$ and the $t$ value is 0.6771 . From these results, it can be concluded that Good Corporate Governance has no effect on Tax Avoidance. Good Corporate Governance in this study uses the number of audit committees and the number of independent commissioners. Good Corporate Governance has no effect on Tax Avoidance because the proportion of independent commissioners in a company does not guarantee that the company does not do tax avoidance. The absence of this influence indicates that the existence of independent commissioners is not effective in monitoring management performance to suppress tax avoidance practices. Other than that,

Meanwhile, the audit committee has no influence on tax avoidance, proving that the existence of the audit committee with the task of supervising the company's operational performance is not going well. The existence of the audit committee in the good corporate governance mechanism does not play an active role in determining policies related to tax burden policies related to tax avoidance activities. The number of members of the audit committee does not guarantee that they can intervene in the role of determining corporate tax planning. The audit committee, which only performs routine operational tasks, such as reviewing reports and selecting external auditors, does not give critical questions and analyzes in depth the conditions of control and the implementation of responsibilities by management.

\section{Effect of Management Compensation on Tax Avoidance}

Table 8. Effect of Management Compensation on Tax Avoidance

Dependent Variable: TA

Method: Least Squares Panel

Date: 02/02/21 Time: 22:02

Sample: 20152019

Periods included: 5

Cross-sections included: 8

Total panel (balanced) observations: 40

\begin{tabular}{|c|c|c|c|c|}
\hline Variable & Coefficient & Std. Error & t-Statistic & Prob. \\
\hline C & 0.313324 & 3.569898 & 0.087768 & 0.9305 \\
\hline KM & -0.300150 & 0.117527 & -2.553882 & 0.0150 \\
\hline
\end{tabular}

Table 8 shows that the p-value is smaller than 0.05 . When compared with an alpha value of $5 \%$, this significance value is smaller $(0.0150<0.05)$ and the $t$ value is -2.5538 . From these results, it can be concluded that Management Compensation has a negative effect on Tax Avoidance. This shows that the large amount of compensation given to management will make tax avoidance actions taken by the company smaller. Interpretation of the test results that the compensation given to management can be a corporate governance mechanism to limit the opportunistic actions of managers by doing tax avoidance. 


\section{Conclusion}

Based on the results of this study, the following conclusions can be drawn:

1. The test results show that Corporate Social Responsibility has a positive effect on tax avoidance in mining sector companies in Indonesia in 2015 - 2019. Corporate Social Responsibility activities have a positive effect on tax avoidance because there are several items of Corporate Social Responsibility carried out by companies that are expenses that can be charged as expenses. deductible expenses, for example a scholarship program with certain criteria, public health programs in the form of free blood checks, free cataract surgery with certain criteria, environmental preservation in the form of reforestation or mass planting of mangrove trees on the shore to prevent abrasion, business capital support for MSMEs, and etc. Besides, some pa company that carries out social responsibility solely uses social responsible actions to get a positive image so that the company can cover up their socially irresponsible actions such as tax avoidance.

2. The test results show that Good Corporate Governance has no effect on tax avoidance. This shows that the existence of independent commissioners is not effective in monitoring the performance of company management to suppress tax avoidance practices. In addition, the placement or addition of members of the independent board of commissioners is only possible to fulfill the stipulated regulations. The existence of the audit committee in the good corporate governance mechanism does not play an active role in determining policies related to tax burden policies related to tax avoidance activities. The number of audit committee members does not guarantee that they can intervene in the role of determining tax planning in the form of corporate tax avoidance.

3. The test results show that management compensation has a negative effect on tax avoidance. This indicates that the large amount of compensation provided to management will make tax avoidance actions taken by the company smaller. Interpretation of the test results that the compensation given to management can be a corporate governance mechanism to limit the opportunistic actions of managers by doing tax avoidance. The size of the compensation package given to management can encourage management to carry out efficiency in the burden that must be incurred by the company through other mechanisms besides taking tax avoidance measures.

\section{References}

Abadi, G. dan. (2017). Strategi pemasaran untuk meningkatkan daya saing bigmo pada PT. Ultra Prima Abadi. Universitas Tarumanegara.

Amri, M. (2017). Pengaruh Kompensasi Manajemen Terhadap Penghindaran Pajak Dengan Moderasi Diversifikasi Gender Direksi Dan Preferensi Risiko Eksekutif Perusahaan Di Indonesia. Jurnal ASET (Akuntansi Riset), 9(1), 1. https://doi.org/10.17509/jaset.v9i1.5253

Budiadnyani, N. P. (2020). Pengaruh Kompensasi Manajemen Pada Penghindaran Pajak Dengan Kepemilikan Instutisional Sebagai Variabel Pemoderasi. Jurnal Ilmiah Akuntansi Dan Bisnis, 5(1), 67-90.

Chairil Anwar, P. (2016). Manajemen Perpajakan Strategi Perencanaan Pajak dan Bisnis. PT.Gramedia Pustaka Utama.

Chasbiandani, T., Astuti, T., \& Ambarwati, S. (2020). Pengaruh Corporation Risk dan Good Corporate Governance terhadap Tax Avoidance dengan Kepemilikan 
Institusional sebagai Variable Pemoderasi. Kompartemen: Jurnal Ilmiah Akuntansi, 17(2), 115-129. https://doi.org/10.30595/kompartemen.v17i2.4451

Chaudhary, A. (2016). Forest Management Meta-Analysis S1.

Christopher S. Armstrong, Jennifer L. Blouin, D. F. L. (2012). The incentives for tax planning. Journal of Accounting and Economics, 53(1-2), 391-411. https://doi.org/https://doi.org/10.1016/j.jacceco.2011.04.001

Cita, I. G. A., \& Supadmi, N. L. (2019). Pengaruh Financial Distress dan Good Corporate Governance pada Praktik Tax Avoidance. E-Jurnal Akuntansi, 29(3), 912. https://doi.org/10.24843/eja.2019.v29.i03.p01

Company, P., Jensen, C., \& Meckling, H. (1976). Theory Of The Firm: Managerial Behavior, Agency Costs And Ownership Structure I . Introduction and summary In this paper WC draw on recent progress in the theory of ( 1 ) property rights, firm . In addition to tying together elements of the theory of e. 3, 305-360.

Dewi, G. A. P., \& Sari, M. M. R. (2015). Pengaruh Insentif Eksekutif, Corporate Risk dan Corporate Governance Pada Tax Avoidance. Jurnal Akuntansi, Universitas Udayana, 50-67.

Dharma, I. M. S., \& Ardiana, P. A. (2016). Pengaruh Leverage, Intensitas Aset Tetap, Ukuran Perusahaan, Dan Koneksi Politik Terhadap Tax Avoidance. E-Jurnal Akuntansi Universitas Udayana, 15(1), 584-613.

Dharma, N. (2017). Pengaruh Corporate Social Responsibility Dan Capital Intensity Terhadap Tax Avoidance. In E-Jurnal Akuntansi (Vol. 18, Issue 1, pp. 529-556).

Friana, H. (2019). DJP Dalami Dugaan Penghindaran Pajak PT Adaro Energy. Tirto. https://tirto.id/djp-dalami-dugaan-penghindaran-pajak-pt-adaro-energy-edKk

Gantino, R. (2016). Pengaruh Corporate Social Responsibility Terhadap Kinerja Keuangan Perusahaan Manufaktur yang Terdaftar di Bursa Efek Indonesia periode 2008-2014. Jurnal Dinamika Akuntansi Dan Bisnis, 3(2), 19-32. https://doi.org/10.24815/jdab.v3i2.5384

Ghozali, I. (2017). Analisis Multivariate dan Ekonometrika: Teori, Konsep dan Aplikasi dengan menggunakan EViews 10. In Badan Penerbit Universitas Diponegoro.

Hidayat, K., Ompusunggu, A. P., Suratno, H., Akuntansi, M., Pancasila, U., Sawah, J. S., \& Hidayat, K. (2016). Pengaruh Corporate Social Responsibility Terhadap Agresivitas Pajak Dengan Insentif Pajak Sebagai Pemoderasi. Jurnal Ilmiah Akuntansi Fakultas Ekonomi, 2(2), 39-58.

Hidayati, N., \& Fidiana. (2017). Pengaruh Corporate Social Responsibility dan Good Corporate Governance terhadap Pengindaran Pajak. Jurnal Ilmu Dan Riset Akuntansi, 6, 1053-1070.

Indonesia P.U.G.C.G. (2006). Komite Nasional Kebijakan Governance.

Lanis, R., \& Richardson, G. (2013). Corporate social responsibility and tax aggressiveness: A test of legitimacy theory. Accounting, Auditing and Accountability Journal, 26(1), 75-100. https://doi.org/10.1108/09513571311285621

Mayangsari, Cindy, Zirman, dan Haryani, E. (2015). Pengaruh Kompensasi Eksekutif, Kepemilikan Saham Eksekutif, Preferensi Risiko Eksekutif, dan Laverege terhadap Penghindaran Pajak. 2 (2), 1-15.

Kunyanti, S. A., \& Mujiono, M. (2021). Community Empowerment-based Corporate Social Responsibility Program in Panglima Raja Village. International Journal on Social Science, Economics and Art, 11(1), 12-19.

Oliviana, A., \& Muid, D. (2019). Pengaruh Good Corporate Governance Dan Ukuran Perusahaan Terhadap Tax Avoidance. Diponegoro Journal Of Accounting, 8(3), 1-11.

Rahmawati, A., Endang, M. G. W., \& Agusti, R. R. (2015). Pengaruh pengungkapan Corporate Social Responsibility dan Corporate Governance Terhadap Tax Avoidance. Jurnal Perpajakan, 1(2), 139-166. 
Rokhlinasari, S. (2016). Teori-Teori dalam Pengungkapan Informasi Corporate Social Responsibility Perbankan. 1-11.

Rosa Dewinta, I., \& Ery Setiawan, P. (2016). Pengaruh Ukuran Perusahaan, Umur Perusahaan, Profitabilitas, Leverage, Dan Pertumbuhan Penjualan Terhadap Tax Avoidance. E-Jurnal Akuntansi Universitas Udayana, 14(3), 1584-1615.

Rosadi, F. (2019). Fenomena Tax Ratio Indonesia. Media Keuangan. https://mediakeuangan.kemenkeu.go.id/Home/Detail/91/fenomena-tax-ratioindonesia

Rudito, B., \& Famiola, M. (2013). Corporate Social Responsibility.

Setyaningsih. (2018). Peran Kepemilikan Institusional dan Transparansi Perusahaan sebagai Pemoderasi Pada Hubungan Penghindaran Pajak dengan Nilai Perusahaan. Accounting Globa Journal, 2(1), 49-63.

Sikula, R. R. (1981). A Crucial Issue, School-Community Relations: A Systematic Approach (p. 442).

Solihin, I. (2018). Corporate Social Responsibility From Charity to Sustainability. Salemba Empat.

Sri Ardani, N. K., \& Mahyuni, L. P. (2020). Penerapan Corporate Social Responsibility (CSR) dan Manfaatnya Bagi Perusahaan. Jurnal Manajemen Bisnis, 17(1), 12. https://doi.org/10.38043/jmb.v17i1.2339

Suprasto, I. M. A. N. dan H. B. (2018). Pengaruh Profitabilitas, Leverage, Corporate Governance, dan Karakter Eksekutif pada Tax Avoidance. E-Jurnal Akuntansi, 22(3), 2016-2039. https://doi.org/10.24843/EJA.2018.v22.i03.p14

Suripto, S., \& Sugiyanto, S. (2019). Intensitas Modal Memoderasi Pengaruh Kompensasi Manajemen Dan Pertumbuhan Ekonomi Terhadap Manajemen Pajak Perusahaan Sektor Perbankan Yang Terdaftar Di Bursa Efek Indonesia. Proceedings Universitas Pamulang, 1(1).

Suripto, S. (2020, February). Pengaruh Pemanfaatan Tax Haven, Withholding Taxes, Dan Ukuran Komite Audit Terhadap Praktik Thin Capitalization. In Proseding Seminar Nasional Akuntansi (Vol. 2, No. 1).

Suripto, S. (2019). Corporate Social Responsibility And Creating Shared Value: A Preliminary Study From Indonesia. International Journal Of Contemporary Accounting, 1(1), 23-36.

Sidiq, Rd Siti Sofro, and Ashaluddin Jalil. "Virtual World Solidarity: How Social Solidarity is Built on the Crowdfunding Platform Kitabisa. com." Webology 18, no. 1 (2021).

Wijayanti, A., Wijayanti, A., \& Samrotun, Y. C. (2016). Pengaruh Karakteristik Perusahaan, Gcg Dan Csr Terhadap Penghindaran Pajak. Seminar Nasional IENACO ,$- 2337-4349$.

Winata, F. (2014). Pengaruh Corporate Governance Terhadap Tax Avoidance Pada Perusahaan Yang Terdaftar Di Bursa Efek Indonesia Tahun 2013. Tax \& Accounting Review, 4 (1)(1), 1-11.

Wulandari, C. D. P. (2018). Pengaruh Profitabilitas, Komite Audit, Kualitas Audit, Komisaris Independen, Kepemilikan Institusional, Dewan Direksi Dan Financial Distress, Terhadap Penghindaran Pajak. Skripsi. Fakultas Ekonomi. Universitas Islam Indonesia: Yogyakarta. 127.

Zarkasyi. (2019). Good Corporate Governance Pada Badan Usaha Manufaktur, Perbankan, dan Jasa Keuangan Lainnya. Alfabeta. 